\title{
Pengaruh Pendapatan Asli Daerah dan Dana Perimbangan Terhadap Belanja Modal Pemerintahan Daerah Kabupaten
}

\section{The Effect of Local Own Revenue and Balancing Funds on Capital Expenditures of Regency Government}

\author{
Eky Ermal Muttaqin*, Warsani Purnama Sari, Pandapotan Ritonga \& \\ Dinda Fadillah
}

Program Studi Akuntansi, Fakultas Ekonomi dan Bisnis, Universitas Medan Area, Indonesia

\begin{abstract}
Abstrak
Penelitian ini bertujuan untuk mengetahui pengaruh pendapatan asli daerah dan dana perimbangan secara parsial dan simultan terhadap belanja modal Pada Pemerintahan Kabupaten Langkat. Populasi dalam penelitian ini adalah Laporan Realisasi Anggaran APBD Pemerintahan Kabupaten Langkat dengan sampel selama 5 tahun mulai dari tahun 2014-2018 dan Jenis penelitian yang digunakan adalah kuantitatif dengan pendekatan asosiatif. Jenis data yang digunakan adalah data sekunder berupa Laporan APBD yang diperoleh dari Badan Pengelolaan Keuangan dan Aset Daerah Kabupaten Langkat. Teknik pengumpulan data dengan dokumentasi dan observasi dengan teknik analisis data menggunakan regresi linier berganda. Hasil penelitian menunjukkan bahwa secara parsial variabel pendapatan asli daerah berpengaruh signifikan terhadap belanja modal dan dana perimbangan berpengaruh positif dan signifikan terhadap belanja modal Kabupaten Langkat dan secara simultan pendapatan asli daerah dan dana perimbangan berpengaruh positif dan signifikan terhadap belanja modal Kabupaten Langkat.

Kata Kunci: Pendapatan Asli daerah, Dana Perimbangan, Belanja Modal
\end{abstract}

\begin{abstract}
This study aims to determine the effect of regional own-source revenue and balance funds on capital expenditure in Langkat District Government. This type of research is quantitative with an associative approach. The type of data used is secondary data in the form of APBD reports obtained from the Regional Financial Management Agency and Langkat District. Data collection techniques with documentation and observation with data analysis techniques using multiple linear regression. The results showed that partially local revenue variables had significant effect on capital expenditure and balancing funds had a significant and significant effect on capital expenditure in Langkat District and simultaneously regional original income and balance funds had a positive and significant effect on capital expenditure in Langkat District.
\end{abstract}

Keywords: Regional Original Revenue, Balance Funds, Capital Expenditures

How to Cite: Muttaqin, E.E. Sari, W., Ritonga, P., \& Fadillah, D. (2021). Pengaruh Pendapatan Asli Daerah dan Dana Perimbangan Terhadap Belanja Modal Pemerintahan Daerah Kabupaten. Economics, Business and Management Science Journal, 1(1): 22-28

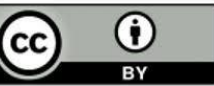




\section{PENDAHULUAN}

Tingkat pertumbuhan ekonomi menjadi salah satu tujuan penting pemerintah daerah maupun pemerintah pusat (Maryati, U. 2010). Untuk mendorong pertumbuhan ekonomi, diharapkan desentralisasi fiskal dapat memberikan dampak yang positif dan signiflkan terhadap pertumbuhan ekonomi (Mukiwihando, R. 2020). Dalam era Desentralisasi fiskal diharapkan terjadinya peningkatan pelayanan diberbagai sektor terutama sektor publik. Peningkatan layanan publik ini diharapkan dapat meningkatkan daya tarik investor untuk membuka usaha di daerah. Harapan ini tentu saja dapat terwujud apabila ada upaya pemerintah dengan memberikan berbagai fasilitas untuk investasi (Kusmayadi, \& Qomari, N. 2019). Konsekuensinya pemerintah perlu memberikan alokasi belanja yang lebih besar untuk tujuan ini. Salah satu belanja yang dilakukan oleh pemerintah daerah adalah belanja modal (Antari, \& Sedana, 2018).

Menurut Halim (2014) "Belanja Modal merupakan pengeluaran anggaran untuk perolehan asset tetap dan aset lainnya yang memberikan manfaat lebih dari satu periode akuntansi." Anggaran ini sebenamya dimaksudkan untuk memenuhi kebutuhan publik akan sarana dan prasarana umum yang disediakan oleh pemerintah daerah.

Tujuan PAD sendiri adalah untuk memberikan kewenangan kepada Pemerintah Daerah untuk mendanai pelaksanaan otonomi daerah sesuai dengan potensi Daerah sebagai perwujdan Desentralisasi (Montolalu, J. (2017). Peningkatan PAD diharapkan mampu mendorong meningkatkan investasi belanja modal pemerintah daerah sehingga kulaitas pelayanan publik semakin baik (Arini, P. R., \& Kusuma, M. W. 2019).

Kemampuan setiap daerah tidak sama dalam mendanai berbagai kegiatan, hal ini menimbulkan adanya kesenjangan fiskal antar satu daerah dengan daerah lainnya. Untuk mengatasi hal tersebut, Pemerintah mengalokasikan dana transfer yang bersumber dari APBN untuk mendanai kebutuhan daerah dalam pelaksanaan desentralisasi. Menurut Amandemen Undang-Undang Pemda (UU Republik Indonesia No. 23 Tahun 2014) tentang Pemerintahan Daerah bahwa Dana perimbangan meliputi Dana Bagi Hasil, Dana Alokasi Umum (DAU), Dana Alokasi Khusus (DAK). Dana Alokasi Umum (DAU) salah satu dana perimbangan dari pemerintah yang pengalokasiannya menekankan aspek pemerataan dan keadilan yang selaras dengan penyelenggaraan urusan pemerintah (Nurdiwaty, D., Zaman, B., \& Kristinawati, E. 2017). Perimbangan keuangan antara pemerintah pusat dan pemerintah daerah pada hakekatnya mencakup pembagian keuangan antara pemerintah pusat dan pemerintah daerah secara proporsional, demokratis, adil, dan transparan dengan memperhatikan potensi, kondisi dan kebutuhan daerah (Budianto, B., \& Alexander, S. W. (2017). Dengan demikian, perimbangan keuangan antara pemerintah pusat dan pemerintah daerah adalah merupakan suatu sistem yang menyeluruh dalam rangka penyelenggaraan asas desentralisasi, dekonsentrasi maupun tugas pembatuan (Purwantoro, P., \& Setyowati, L. 2019)

Berdasarkan kutipan Medan bisnis daily.com-Langkat. Badan Pendapatan Daerah (Bapenda) Kabupaten Langkat dari tahun 2014 - 2018 dinilai belum mampu dalam meningkatkan Pendapatan Asli Daerah (PAD). Penentuan target PAD belum mencerminkan potensi yang sebenarnya. Hal itu disampaikan Ketua Gerakan Rakyat Arus Bawah (GeRAH) Kabupaten Langkat, Al Fuad Nasir, Kamis (8/8/2019). Hal ini menunjukkan bahwa Pemerintahan Kabupaten Langkat masih belum mampu menempatkan anggaran yang sesuai, sehingga masih banyak hal -hal yang seharusnya diperbaiki serta ditindak lanjuti sebagai program kerja yang lebih baik. Namun, terkait dengan hal ini Pemerintahan Kabupaten Langkat masih belum terlihat efektif serta efisien dalam merealisasikan anggarannya.

\section{METODE PENELITIAN}

Penelitian ini menggunakan metode deskriptif analisis dengan pendekatan asosiatif. Adapun populasi dalam penelitian ini adalah seluruh laporan keuangan pemerintah di kabupaten langkat dengan sampel yang digunakan dalam penelitian ini adalah Pendapatan Asli Daerah, Dana Perimbangan, serta Belanja Modal pada Pemerintahan Kabupaten Langkat adalah 5 tahun 20142018. 
Uji asumsi klasik berupa Uji Normalitas, multikoliearitas, autokorelasi. Kemudian, uji analisis linear berganda, uji hipotesis dan uji koefisien determinasi dilaksanakan dalam metode pada penelitian ini.

\section{HASIL DAN PEMBAHASAN \\ Uji Asumsi Klasik}

\section{Uji Normalitas}

Untuk pendekatan analisis statistik dengan menggunakan uji One Sample KolmogorovSminrnov One. Sample Kolmogorov-Sminrnov yaitu dengan ketentuan apabila nilai signifikan $>0,05$ maka data terdistribusi normal, jika nilai signifikan $<0,05$ maka data tidak normal.

\begin{tabular}{|c|c|c|}
\hline \multicolumn{3}{|c|}{ One-Sample Kolmogorov-Smirnov Test } \\
\hline & & Unstandardized Residual \\
\hline$\underline{\mathrm{N}}$ & & 15 \\
\hline \multirow{2}{*}{ Normal Parameters ${ }^{\mathrm{a}, \mathrm{b}}$} & Mean & .0000000 \\
\hline & Std. Deviation & .27930802 \\
\hline \multirow{3}{*}{$\begin{array}{l}\text { Most } \\
\text { Differences }\end{array}$} & Absolute & .092 \\
\hline & Positive & .083 \\
\hline & Negative & -.092 \\
\hline \multicolumn{2}{|l|}{ Kolmogorov-Smirnov Z } & $\cdot 355$ \\
\hline \multicolumn{2}{|l|}{ Asymp. Sig. (2-tailed) } & 1.000 \\
\hline
\end{tabular}

Berdasarkan hasil tabel 1, diketahui bahwa nilai signifikansi sebesar 1.000 $>0,05$ dengan dasar pengambilan keputusan dalam uji normalitas kolmogorov-Smirnov, dapat disimpulkan bahwa data berasumsi normal. Sehingga asumsi atau persyaratan normalitas dalam model regresi sudah terpenuhi.

\section{Uji Multikolinearitas}

Uji multikolinearitas bertujuan untuk menguji apakah model regresi ditemukan adanya korelasi antara variabel bebas (independen).

\section{Tabel 1.2 Uji Multikolinearitas}

\begin{tabular}{|c|c|c|c|c|c|c|c|c|}
\hline \multicolumn{9}{|c|}{ Coefficients $^{\mathbf{a}}$} \\
\hline \multirow{2}{*}{\multicolumn{2}{|c|}{ Model }} & \multicolumn{2}{|c|}{$\begin{array}{l}\text { Unstandardized } \\
\text { Coefficients }\end{array}$} & \multirow{2}{*}{$\begin{array}{l}\text { Standardized } \\
\text { Coefficients } \\
\text { Beta }\end{array}$} & \multirow{2}{*}{$\mathrm{t}$} & \multirow[t]{2}{*}{ Sig. } & \multicolumn{2}{|c|}{$\begin{array}{l}\text { Collinearity } \\
\text { Statistics }\end{array}$} \\
\hline & & $\mathrm{B}$ & Std. Error & & & & Tolerance & VIF \\
\hline \multirow{3}{*}{1} & (Constant) & -6.870 & 5.683 & & -1.209 & .250 & & \\
\hline & Pendapatan Asli Daerah & .785 & .193 & .649 & 4.059 & .002 & .783 & 1.277 \\
\hline & Dana Perimbangan & .497 & .225 & .353 & 2.208 & .047 & .783 & 1.277 \\
\hline
\end{tabular}

a. Dependent Variable: Belanja Modal

Berdasarkan tabel 2 maka dapat disimpulkan bahwa model persamaan regresi tidak terjadi gejala multikolinearitas. Dibuktikan dengan bahwa nilai tolerance untuk setiap variabel lebih besar dari 0,01 dan nilai VIF lebih kecil dari 10.

1. Nilai tolerance lebih besar dari 0,01 yaitu Pendapatan Asli Daerah $(0,783)$ dan nilai tolerance Dana Perimbangan $(0,783)$.

2. Nilai VIF lebih kecil dari 10 yaitu nilai VIF jumlah pendapatan asli daerah (1.277) dan nilai VIF Dana Perimbangan (1,277).

\section{Uji Autokorelasi}

Tabel 1.3 Tabel Uji Autokorelasi

\begin{tabular}{|c|c|c|c|c|c|}
\hline \multicolumn{6}{|c|}{ Model Summary ${ }^{b}$} \\
\hline$\overline{\text { Model }}$ & $\mathrm{R}$ & R Square & Adjusted R Square & Std. Error of the Estimate & Durbin-Watson \\
\hline 1 & $.872^{\mathrm{a}}$ & .760 & .720 & .301605 & .984 \\
\hline \multicolumn{6}{|c|}{ a. Predictors: (Constant), Dana Perimbangan, Pendapatan Asli Daerah } \\
\hline \multicolumn{6}{|c|}{ b. Dependent Variable: Belanja Modal } \\
\hline
\end{tabular}


Berdasarkan output diatas dapat dilihat bahwa nilai DW sebesar 0,984 dan nilai du diperoleh nilai sebesar 1,6148. Nilai DW 0,984 lebih besar dari batas atas (du) sebesar 1,6148 dan kurang dari $(4-d u)>d=(2,3852>0,984)$ sehingga disimpulkan bahwa tidak terdapat autokorelasi.

\section{B. Analisis Regresi Linier Berganda}

Tabel 1.4 Tabel Coefficient Analisis Regresi Berganda

\begin{tabular}{|c|c|c|c|c|c|c|}
\hline \multirow{4}{*}{\multicolumn{2}{|c|}{ Model }} & \multicolumn{3}{|c|}{ Coefficients $^{\mathrm{a}}$} & \multirow{4}{*}{$\mathrm{t}$} & \multirow{4}{*}{ Sig. } \\
\hline & & \multirow{2}{*}{\multicolumn{2}{|c|}{$\begin{array}{l}\text { Unstandardized } \\
\text { Coefficients }\end{array}$}} & Standardized & & \\
\hline & & & & Coefficients & & \\
\hline & & $\mathrm{B}$ & Std. Error & Beta & & \\
\hline \multirow{3}{*}{1} & (Constant) & 6.890 & 5.687 & & 1.212 & 249 \\
\hline & $\begin{array}{l}\text { Pendapatan } \\
\text { Daerah }\end{array}$ & Asli.785 & .193 & 649 & 4.059 & .002 \\
\hline & Dana Perimb & .498 & 225 & .354 & 2.212 & .047 \\
\hline
\end{tabular}

a. Dependent Variable: Belanja Modal

Belanja Modal = 6,890 + 0,785PAD + 0,498Dana Perimbangan

Dari persamaan regresi diatas dapat dijelaskan sebagai berikut :

a. Konstanta sebesar 6,890 menyatakan bahwa jika nilai Pendapatan Asli Daerah $\left(\mathrm{X}_{1}\right)$, Dana Perimbangan $\left(\mathrm{X}_{2}\right)$ dianggap konstan atau bernilai 0,maka Belanja Modal sebesar 6,890.

b. Koefisien regresi variabel Pendapatan Asli Daerah $\left(X_{1}\right)$ sebesar 0,785 artinya apabila Pendapatan Asli Daerah mengalami kenaikan 1\% maka Belanja Modal akan mengalami kenaikan sebesar 0,785 satuan.

c. Koefisien regresi variabel Dana Perimbangan $\left(\mathrm{X}_{2}\right)$ sebesar 0,498 artinya menunjukan apabila Dana Perimbangan mengalami kenaikan 1\% maka Belanja Modal akan mengalami kenaikan sebesar 0,498 satuan.

\section{Uji Hipotesis}

\section{Uji t (Parsial)}

Tabel 1.5

Tabel Uji t (Parsial)

Coefficients $^{\mathbf{a}}$

\begin{tabular}{|c|c|c|c|c|c|c|}
\hline \multirow{3}{*}{\multicolumn{2}{|c|}{ Model }} & \multicolumn{3}{|c|}{ Coefficients $^{\mathrm{a}}$} & \multirow{3}{*}{$\mathrm{t}$} & \multirow{3}{*}{ Sig. } \\
\hline & & \multicolumn{2}{|c|}{ Unstandardized Coefficients } & Standardized Coefficients & & \\
\hline & & $\mathrm{B}$ & Std. Error & Beta & & \\
\hline \multirow{3}{*}{1} & (Constant) & 6.890 & 5.687 & & 1.212 & .249 \\
\hline & $\begin{array}{l}\text { Pendapatan } \\
\text { Daerah }\end{array}$ & sli.785 & .193 & .649 & 4.059 & .002 \\
\hline & Dana Perimbangan & .498 & .225 & .354 & 2.212 & .047 \\
\hline
\end{tabular}

a. Dependent Variable: Belanja Modal

Berdasarkan hasil pengujian secara parsial pengaruh pendapatan asli daerah terhadap belanja modal diperoleh $t_{\text {hitung }}$ pendapatan asli daerah $>t_{\text {tabel }}(4,059>2,178)$ dan signifikan sebesar $0,002<0,05$. Maka dapat disimpulkan secara parsial variabel pendapatan asli daerah berpengaruh signifikan terhadap belanja modal dan sesuai dengan hipotesis $\mathrm{H}_{1}$.

Dan hasil pengujian secara parsial pengaruh dana perimbangan terhadap belanja modal diperoleh $t_{\text {hitung }}$ pendapatan asli daerah $>t_{\text {tabel }}(2,212>2,178)$ dan signifikan sebesar 0,047 $<0,05$. Maka dapat disimpulkan secara parsial variabel dana perimbangan berpengaruh signifikan terhadap belanja modal dan sesuai dengan hipotesis $\mathrm{H}_{2}$.

\section{Uji F (Simultan)}

Tabel 6. Tabel Uji F (Simultan) ANOVAa

\begin{tabular}{|c|c|c|c|c|c|c|}
\hline \multicolumn{7}{|c|}{ ANOVAa } \\
\hline Mod & & Sum of Squares & Df & Mean Square & $\mathrm{F}$ & Sig. \\
\hline & Regression & 3.451 & 2 & 1.725 & 18.968 & $.000 \mathrm{~b}$ \\
\hline \multirow[t]{2}{*}{1} & Residual & 1.092 & 12 & .091 & & \\
\hline & Total & 4.543 & 14 & & & \\
\hline \multicolumn{7}{|c|}{ a. Dependent Variable: Belanja Modal } \\
\hline \multicolumn{7}{|c|}{ b. Predictors: (Constant), Dana Perimbangan, Pendapatan Asli Daerah } \\
\hline
\end{tabular}


Berdasarkan tabel 4.10 dapat dilihat bahwa $\mathrm{F}_{\text {hitung }}$ sebesar 18,968. Sedangkan $\mathrm{F}_{\text {tabel }}$ Dengan kriteria uji f dilakukan pada tingkat $\alpha=5 \%$ dengan nilai $\mathrm{F}_{\text {tabel }}(\mathrm{N} 1=\mathrm{k}-1=1 ; \mathrm{N} 2=\mathrm{n}-\mathrm{k}-1=15-2-1=12$ ) adalah 4,75. Dapat disimpulkan sebagai berikut: Berdasarkan hasil pengujian secara bersamasama pengaruh pendapatan asli daerah dan dana perimbangan terhadap belanja modal diperoleh $F_{\text {hitung }}>F_{\text {tabel }}(18,968>4,75)$ dan signifikan $0,000<0,05$. Maka disimpulkan bahwa secara simultan pendapatan asli daerah dan dana perimbangan secara bersama sama berpengaruh positif signifikan terhadap belanja modal.

\section{Koefisien Determinasi $\left(\mathbf{R}^{2}\right)$}

\begin{tabular}{lllll}
\hline \multicolumn{4}{c}{ Model Summaryb } \\
\hline Model & $\mathrm{R}$ & $\mathrm{R}$ Square & Adjusted R Square & Std. Error of the Estimate \\
\hline 1 & $.872 \mathrm{a}$ & .760 & .720 & .301687 \\
\hline a. Predictors: (Constant), Dana Perimbangan, Pendapatan Asli Daerah \\
\hline b. Dependent Variable: Belanja Modal \\
\hline
\end{tabular}

Berdasarkan hasil pada tabel 4 model regresi diperoleh sebesar 0.804 atau $80,4 \%$. Hal ini menunjukkan bahwa kontribusi Pendapatan Asli Daerah (X1), Dana Perimbangan (X2) terhadap Belanja Modal (Y) sebesar 76\%. Sisanya sebesar $24 \%$ (100\%-76\%) dipengaruhi oleh variabel lain yang tidak disertakan dalam penelitian ini.

\section{HASIL DAN PEMBAHASAN \\ Pengaruh Pendapatan Asli Daerah Terhadap Belanja Modal}

Berdasarkan hasil pengujian secara parsial pengaruh pendapatan asli daerah terhadap belanja modal diperoleh $t_{\text {hitung }}$ pendapatan asli daerah $>t_{\text {tabel }}(-4,059>2,178)$ dan signifikan sebesar 0,002 $>0,05$. Maka dapat disimpulkan secara parsial variabel pendapatan asli daerah berpengaruh positif dan signifikan terhadap belanja modal dan sesuai dengan hipotesis $\mathrm{H}_{1}$. Koefisien regresi variabel Pendapatan Asli Daerah $\left(\mathrm{X}_{1}\right)$ sebesar 0,785 artinya menunjukan apabila Pendapatan Asli Daerah mengalami kenaikan 1\% maka Belanja Modal akan mengalami kenaikan sebesar 0,785 satuan.

Hasil penelitian sejalan denga Made Ari Juniawan dan Ni Putu Santi Suryantini (2018) dan Fani Wiraswasta, M.Pudjihardjo,dan Putu Mahardika Adis (2018) yang menyatakan bahwa Pendapatan Asli Daerah berpengaruh positif signifikan terhadap belanja modal. Pada penelitian saya menyatakan bahwa pendapatan asli daerah berpengaruh positif dan signifikan terhadap belanja modal. Pendapatan asli daerah kabupaten langkat sudah sangat baik untuk membiayai belanja modal pada daerah kabupaten langkat. Semakin besar pendapatan asli daerah dikabupaten langkat maka penerimaan yang digunakan dalam penyediaan dan pengadaan pelayanan dan fasilitas publik yg terbaik untuk masyarakat kabupaten langkat.

\section{Pengaruh Dana Perimbangan Terhadap Belanja Modal}

Berdasarkan hasil pengujian secara parsial pengaruh dana perimbangan terhadap belanja modal diperoleh $t_{\text {hitung }}$ dana perimbangan $>t_{\text {tabel }}(2,212$

$>2,018$ ) dan signifikan sebesar 0,047<0,05. Maka dapat disimpulkan secara parsial variabel dana perimbangan berpengaruh positif dan signifikan terhadap belanja modal sesuai dengan hipotesis $\mathrm{H}_{2}$. Koefisien regresi variabel Dana Perimbangan $\left(\mathrm{X}_{2}\right)$ sebesar 0,498 artinya menunjukan apabila Dana Perimbangan mengalami kenaikan 1\% maka Belanja Modal akan mengalami kenaikan sebesar 0,498 satuan.

Hasil penelitian sejalan denga Made Ari Juniawan dan Ni Putu Santi Suryantini (2018) dan Fani Wiraswasta, M.Pudjihardjo,dan Putu Mahardika Adis (2018) yang menyatakan bahwa dana perimbangan berpengaruh positif signifikan terhadap belanja modal. Pada penelitian saya bahwa Semakin besar dana perimbangan makan semakin besar pula pengalokasian terhadap belanja modal. Pemerintah pusat memberikan dana perimbangan dalam rangka menciptakan keadilan dalam pembagian sumber daya baik untuk kepentingan nasional maupun kepentingan rakyat. Dana Perimbangan sudah memenuhi segala kegiatan dikabupaten langkat

Pengaruh Pendapatan Asli Daerah dan Dana Perimbangan Terhadap Belanja Modal. Berdasarkan hasil pengujian secara bersama-sama pengaruh pendapatan asli daerah dan dana 
perimbangan terhadap belanja modal diperoleh $F_{\text {hitung }}>F_{\text {tabel }}(18,968>4,07)$ dan signifikan 0,000 $<0,05$. Maka disimpulkan bahwa secara simultan pendapatan asli daerah dan dana perimbangan secara bersama sama berpengaruh positif signifikan terhadap belanja modal.Hasil penelitian sejalan dengan Made Ari Juniawan dan Ni Putu Santi Suryantini (2018) dan Fani Wiraswasta, M.Pudjihardjo,dan Putu Mahardika Adis (2018) yang menyatakan bahwa pendapatan asli daerah dan dana perimbangan berpengaruh positif signifikan terhadap belanja modal.

\section{SIMPULAN}

Pendapatan Asli Daerah secara parsial berpengaruh positif dan signifikan terhadap Belanja Modal pada Pemerintahan Kabupaten Langkat. Dapat diketahui bahwa kabupaten langkat memang menjadi salah satu lokasi prioritas bagi pemerintah pusat dalam tata kelola keuangan. Selanjutnya dari hasil yang diperoleh bahwa dana Perimbangan secara parsial berpengaruh positif terhadap Belanja Modal pada Pemerintahan Kabupaten Langkat, ini terlihat masih adanya sinergitas pusat melalui desentralisasi kepada pemerintah daerah dalam berkontribusi terhadap alokasi keuangan negara. Pendapatan Asli Daerah dan Dana Perimbangan secara simultan berpengaruh positif dan signifikan terhadap Belanja Daerah pada Pemerintahan Langkat, artinya sinergitas antara masyarakat dan sektor publik dapat terlaksana jika pengelolaan telah terlaksana dengan baik di kabupaten Langkat.

\section{DAFTAR PUSTAKA}

Antari, N. P. G. S., \& Sedana, I. B. P. (2018). Pengaruh Pendapatan Asli Daerah dan Belanja Modal Terhadap Kinerja Keuangan Pemerintah Daerah. E-Jurnal Manajemen Universitas Udayana, 7 (2).

Arini, P. R., \& Kusuma, M. W. (2019). Pengaruh belanja modal dan pendapatan asli daerah terhadap investasi swasta di indonesia dengan pertumbuhan ekonomi sebagai variabel intervening. Jurnal Riset Akuntansi Mercu Buana, 5(1), 28-38.

Arsyad, Lincolin.2015.Ekonomi PembangunanEdisi Kelima: UPP STIM YKPN. Yogyakarta

Budianto, B., \& Alexander, S. W. (2017). Pengaruh Pad Dan Dana Perimbangan Terhadap Kinerja Keuangan Pemerintah Kabupaten/Kota Di Provinsi Sulawesi Utara. Jurnal EMBA: Jurnal Riset Ekonomi, Manajemen, Bisnis dan Akuntansi, 4(4).

Ghozali, I. (2013). Aplikasi Multivariate dengan Program SPSS. Badan Penerbit Universitas Diponegoro: Semarang

Halim, A. (2014). Manajemen Keuangan Sektor Publik: Problematika Penerimaan dan Pengeluaran Pemerintah.Jakarta: Salemba Empat.

J.Made Ari, S. Ni Putu Santi. (2018). Pengaruh PAD, DAU dan DAK terhadap Belanja Modal Kota dan Kabupaten di Provinsi Bali

Kusmayadi, R. C. R., \& Qomari, N. (2019). Identifikasi Regulasi Peningkatan Investasi dan Perluasan Lapangan Kerja di Kabupaten Malang. Iqtishodia: Jurnal Ekonomi Syariah, 4(2), 207-234.

Mardiasmo. (2009). Akuntansi Sektor Publik. Edisi 4. ANDI. Yogyakarta.

Maryati, U. (2010). Pengaruh Pendapatan Asli Daerah (PAD), Dana Alokasi Umum (DAU) dan Dana Alokasi Khusus (OAK) Tehadap Pertumbuhan Ekonomi: Studi Kasus Sumatera Barat. Jurnal Akuntansi \& Manajemen, 5(2), 68-84.

Montolalu, J. (2017). Analisis Penerimaan Pendapatan Asli Daerah Serta Kontribusinya terhadap Anggaran Pendapatan dan Belanja Daerah Kabupaten Minahasa Selatan. JURNAL ADMINISTRASI BISNIS (JAB).

Mukiwihando, R. (2020). Pengaruh tata kelola terhadap pencapaian tujuan desentralisasi fiskal. JURNAL PKN (Jurnal Pajak dan Keuangan Negara), 1(2), 114-123.

Nurdiwaty, D., Zaman, B., \& Kristinawati, E. (2017). Analisis pengaruh pertumbuhan ekonomi, pendapatan asli daerah, dana perimbangan dan lain-lain pendapatan yang sah terhadap belanja modal di kabupaten/kota Jawa Timur. Jurnal Aplikasi Bisnis, 17(1), 43-59.

P. Pande Putu Maesa Eka Putra, D. Made Heny Urmila.(2018). Pengaruh PAD dan Dana Perimbangan terhadap Belanja Modal dan Kesejahteraan Masyarakat Kabupaten Karangasem Provinsi Bali

Purwantoro, P., \& Setyowati, L. (2019). Pengaruh Pendapatan Daerah terhadap Belanja Daerah Provinsi Jawa Tengah. Jurnal Bisnis dan Ekonomi, 26(1).

Sari, N. (2018). Pengaruh Dana Perimbangan dan Pendapatan Asli Daerah Terhadap Belanja Modal Kabupaten Lampung Selatan dalam Perspektif Ekonomi Islam

Sidik, M. (2000). Perimbangan Keuangan antara Pemerintah Pusat dan Daerah serta Implikasinya Terhadap Pembiayaan Otonomi Daerah:Laporan Khusus, Yayasan Indonesia Forum, Jakarta. 
Eky Ermal Muttaqin, Warsani Purnama Sari, Pandapotan Ritonga \& Dinda Fadillah, Pengaruh

Kano, J.R. (2005). Prospek Otonomi Daerah di Republik Indonesia : Identifikasi Faktor yang Mempengaruhi Penyelenggaraannya. : Rajawali Press. Jakarta

Santoso, P.B. dan Rahayu, R.P. (2005), Analisis Pendapatan Asli Daerah (PAD) dan Faktor- Faktor Yang Mempengaruhinya Dalam Pelaksanaan Otonomi Daerah Di, Dinamika Pembangun. Kabupaten Kediri

Siregar, S. (2012). Statistik Parametik. Jakarta: Bumi Aksara: Bandung:

Sugiyono. (2011). Metode Penelitian Kuantitatif, Kualitatif dan R\&D.Alfabeta Bandung

Sugiyono. (2016). Metode Penelitian Kuantitatif, Kualitatif dan R\&D. Bandung:

Suharsimi, A. (2002). Prosedur Penelitian Pendekatan Praktek. Jakarta: PT. Rineka Cipta.

Suharyadi. (2008). Statistik Untuk Ekonomi dan Keuangan Modern Edisi 2 Buku 1. Jakarta: Salemba Empat. W.Fani, Pudjihardjo.M, A.Putu Mahardika.(2018). Pengaruh Dana Perimbangan dan Dana Pendapatan Asli Daerah (PAD) terhadap Pertumbuhan Ekonomi Melalui Belanja Modal di Kota dalam Wilayah Jawa Timur

Ani, A. (2008). Hubungan Keuangan antara Pemerintah Pusat dan Daerah di Indonesia.: PT. Raja Grafindo Persada. Jakarta

Keputusan Menteri Dalam Negeri Nomor 29 Tahun 2002 Tentang Pedoman Pengurusan, Pertanggungjawaban dan Pengawasan Keuangan Daerah Serta Tata Cara Penyusunan APBD, Pelaksanaan Tata Usaha Keuangan Daerah dan Penyusunan Perhiitungan APBD. (2002).

Undang-Undang Nomor 22 Tahun 1999 Tentang Pemerintah Daerah. (n.d.).

Undang-Undang Nomor 42 Tahun 2004 tentang Pemerintahan Daerah. (n.d.).

Undang-Undang Nomor 33 Tahun 2004 tentang Perimbangan Keuangan Antara Pemerintah Pusat dan Pemerintah Daerah. (2004).

Peraturan Pemerintah No.58 Tahun 2005 tentang Pengelolaan Keuangan Daerah. (2005).

Peraturan Pemerintah Nomor 55 Tahun 2005 Tentang Dana Perimbangan. (2005).

Peraturan Dalam Negeri Nomor 13 Tahun 2006 Tentang Pedoman Pengelolaan Keuangan Daerah. (2006) 